University of Nebraska - Lincoln

DigitalCommons@University of Nebraska - Lincoln

$1-29-1988$

\title{
Seasonal Variations in the Diurnal Characteristics of Heavy Hourly Precipitation across the United States
}

Julie A. Winkler

Michigan State University

Brent Robert Skeeter

University of Nebraska - Lincoln

Paul Yamamoto

University of Nebraska - Lincoln

Follow this and additional works at: https://digitalcommons.unl.edu/natrespapers

Part of the Natural Resources and Conservation Commons, Natural Resources Management and Policy Commons, and the Other Environmental Sciences Commons

Winkler, Julie A.; Skeeter, Brent Robert; and Yamamoto, Paul, "Seasonal Variations in the Diurnal Characteristics of Heavy Hourly Precipitation across the United States" (1988). Papers in Natural Resources. 1108.

https://digitalcommons.unl.edu/natrespapers/1108

This Article is brought to you for free and open access by the Natural Resources, School of at DigitalCommons@University of Nebraska - Lincoln. It has been accepted for inclusion in Papers in Natural Resources by an authorized administrator of DigitalCommons@University of Nebraska - Lincoln. 


\title{
Seasonal Variations in the Diurnal Characteristics of Heavy Hourly Precipitation across the United States
}

\author{
JULIE A. WINKLER \\ Department of Geography, Michigan State University, East Lansing, Michigan \\ BRENT R. SKeETER AND PAUL D. YAMAMOTO \\ Department of Geography, University of Nebraska-Lincoln, Lincoln, Nebraska
}

(Manuscript received 17 August 1987, in final form 29 January 1988)

ABSTRACT

\begin{abstract}
Hourly precipitation data from 1967 to 1983 for the coterminous United States were harmonically analyzed in order to document the diurnal variability of several categories of heavy hourly precipitation during winter, spring, summer, and autumn. The analysis revealed that the diurnal characteristics of hourly precipitation vary considerably with season, geographic region, and precipitation intensity. During winter and spring, a weak, latemorning frequency maximum prevails for the lightest $\left(2.5-6.2 \mathrm{~mm} \mathrm{~h}^{-1}\right)$ precipitation category. As intensity increases (to $6.3-12.6,12.7-25.3$, and $\geqslant 25.4 \mathrm{~mm} \mathrm{~h}^{-1}$ ), the amplitude of the diurnal cycle also increases, and a nocturnal maximum becomes apparent across much of the eastern and central United States. In summer, the diurnal cycle is strongly modulated for all categories. The nocturnal region decreases in areal extent at this time of year, as an afternoon maximum becomes established across the southern and eastern states. In autumn, the nocturnal region again increases in size, although the area it encompasses is smaller than that during winter and spring. Seasonal variations in the semidiurnal cycle are more ambiguous due to the dominance of the diurnal cycle at most locations, although secondary maxima and minima are most likely south of the Great Lakes and in eastern and central Texas. Comparison with the results of previous studies indicates that different definitions of "winter," "spring," "summer," and "autumn" can lead to divergent descriptions of the diurnal cycle of hourly precipitation.
\end{abstract}

\section{Introduction}

The diurnal variability of precipitation has long generated considerable interest among atmospheric scientists. Over the past century, numerous researchers have attempted to determine the time of day during which precipitation is most likely to occur across different regions of the United States (e.g., Kincer 1916; Wallace 1975; Mass 1982; Balling 1985). However, in spite of the popularity of this research topic, the diurnal characteristics of precipitation remain incompletely understood. In particular, the diurnal variations of heavy hourly precipitation have not been well documented, as previous studies primarily have been concerned with light and moderate hourly precipitation rates. For example, both Wallace (1975) and Balling (1985) defined a "heavy" event as a precipitation amount of only $\geqslant 2.5 \mathrm{~mm} \mathrm{~h}^{-1}$. The few studies that have included a description of the diurnal cycle for larger $\left(>5\right.$ and $>10 \mathrm{~mm} \mathrm{~h}^{-1}$ ) precipitation amounts either have been limited to small areas such as Florida

Corresponding author address: Professor Julie A. Winkler, Department of Geography, Michigan State University, East Lansing MI 48824-1115.
(Schwartz and Bosart 1979), the northeastern United States (Landin and Bosart 1985), and the Rocky Mountains/Great Plains region (Riley et al. 1987), or have dealt only with the summer season (Winkler 1987).

This study expands upon earlier investigations by documenting in greater detail the diurnal variability of intense hourly precipitation across the coterminous United States. Harmonic analysis is used to describe the diurnal and semidiurnal cycles of several categories of heavy hourly precipitation during winter, spring, summer, and autumn. Emphasis is placed on identifying important seasonal and geographic variations in the diurnal phasing of intense precipitation. Also, changes in the diurnal and semidiurnal cycles with increases in precipitation intensity are examined.

A documentation of the diurnal characteristics of heavy hourly precipitation also can assist in clarifying apparent conflicting results in the hydroclimatological literature on the time of day of greatest threat of flash flood-producing rainstorms (findings of recent studies on the time of onset of extreme rainstorms are summarized in Table 1). Whereas the results of several studies suggest that extreme rainstorms form in the late afternoon and early evening hours soon after the 
TABLE 1. Summary of previous publications on the diurnal variability of heavy precipitation across the United States.

\begin{tabular}{|c|c|c|c|c|}
\hline Reference & Study area & Definition & Season & Diurnal characteristics \\
\hline $\begin{array}{l}\text { Vrcek and Sangster } \\
\text { (1974) }\end{array}$ & $\begin{array}{l}\text { Nebraska, Kansas, } \\
\text { Missouri }\end{array}$ & $>12.7 \mathrm{~mm}$ in $\leqslant 12 \mathrm{~h}$ & $\begin{array}{l}\text { summer (June- } \\
\text { August) }\end{array}$ & late night and early morning \\
\hline Wallace (1975) & Iowa & $\begin{array}{l}6-12 \mathrm{~mm} \mathrm{~h}^{-1} \\
13-25 \mathrm{~mm} \mathrm{~h}^{-1} \\
26-40 \mathrm{~mm} \mathrm{~h}^{-1} \\
\geqslant 41 \mathrm{~mm} \mathrm{~h}^{-1}\end{array}$ & $\begin{array}{l}\text { summer (June- } \\
\text { August) }\end{array}$ & $\begin{array}{l}\text { most frequent between } 1600 \\
\text { and } 2200 \text { LST }\end{array}$ \\
\hline Huff (1978) & Illinois & $25 \mathrm{~mm}$ in $\leqslant 24 \mathrm{~h}$ & N.A.* & $\begin{array}{l}\text { small-scale storms-1300- } \\
1900 \text { CST } \\
\text { large-scale storms-1600- } \\
2030 \mathrm{CST}\end{array}$ \\
\hline $\begin{array}{l}\text { Maddox et al. } \\
\text { (1979) }\end{array}$ & eastern and central U.S. & $\begin{array}{l}\text { flooding reported in } \\
\text { Storm Data }\end{array}$ & N.A. & late night and early morning \\
\hline $\begin{array}{l}\text { Muller and Maddox } \\
\text { (1979) }\end{array}$ & $\begin{array}{l}\text { Tennessee, Illinois, } \\
\text { Missouri, } \\
\text { Nebraska, Utah }\end{array}$ & $\begin{array}{l}\text { flooding reported in } \\
\text { Storm Data }\end{array}$ & N.A. & $\begin{array}{l}\text { Utah-afternoon and } \\
\text { evening; Missouri and } \\
\text { Illinois-evening and } \\
\text { early morning; } \\
\text { Tennessee-morning; } \\
\text { Nebraska-evening and } \\
\text { early morning }\end{array}$ \\
\hline $\begin{array}{l}\text { Schwartz and } \\
\text { Bosart (1979) }\end{array}$ & Florida & $>10 \mathrm{~mm} \mathrm{~h}^{-1}$ & $\begin{array}{l}\text { winter (December- } \\
\text { February), } \\
\text { spring (March- } \\
\text { May), summer } \\
\text { (June-August), } \\
\text { fall (September- } \\
\text { November) }\end{array}$ & $\begin{array}{l}\text { winter_early to } \\
\text { midafternoon; spring, } \\
\text { summer, and fall-- } \\
\text { midafternoon }\end{array}$ \\
\hline $\begin{array}{c}\text { Changnon and } \\
\text { Vogel (1980) }\end{array}$ & Illinois & $\begin{array}{l}\text { maximum } 3-\mathrm{h} \text { total } \\
>25-\mathrm{yr} \text { recurrence } \\
\text { interval }\end{array}$ & $\begin{array}{l}\text { warm season } \\
\text { (May- } \\
\text { September) }\end{array}$ & $\begin{array}{l}\text { most frequent between } 1200 \\
\text { and } 1800 \mathrm{CDT}\end{array}$ \\
\hline $\begin{array}{l}\text { Guttman and Ezell } \\
(1980)\end{array}$ & Appalachia & $\geqslant 25 \mathrm{~mm} \mathrm{~h}^{-1}$ & $\begin{array}{l}\text { warm season } \\
\text { (June- } \\
\text { September) and } \\
\text { annual }\end{array}$ & $\begin{array}{l}\text { warm season-most frequent } \\
\text { between } 1500 \text { and } 1700 \\
\text { LST; annual-relatively } \\
\text { uniformly distributed } \\
\text { throughout the day }\end{array}$ \\
\hline $\begin{array}{l}\text { Maddox et al. } \\
\text { (1980) }\end{array}$ & western U.S. & $\begin{array}{l}\text { flooding reported in } \\
\text { Storm Data }\end{array}$ & N.A. & afternoon and evening \\
\hline Ward $(1981)^{\dagger}$ & Texas & - & $\begin{array}{l}\text { July and } \\
\text { September }\end{array}$ & $\begin{array}{l}\text { "peripheral showers"-_- } \\
\text { afternoon; "core rains"-_ } \\
\text { after midnight }\end{array}$ \\
\hline Crysler et al. (1982) & $\begin{array}{l}\text { Nebraska, } \\
\text { Missouri, } \\
\text { Illinois, } \\
\text { Kentucky, } \\
\text { Tennessee, } \\
\text { Virginia, West } \\
\text { Virginia, } \\
\text { Pennsylvania }\end{array}$ & $\begin{array}{l}25-<51 \mathrm{~mm} \text { in } \leqslant 1 \mathrm{~h} \\
51-<76 \mathrm{~mm} \text { in } \leqslant 2 \mathrm{~h} \\
76-<102 \mathrm{~mm} \text { in } \leqslant 4 \mathrm{~h} \\
\geqslant 102 \mathrm{~mm} \text { in } \leqslant 8 \mathrm{~h}\end{array}$ & N.A. & $\begin{array}{l}\text { short duration events- } \\
\text { afternoon and evening; } \\
\text { extreme events-late } \\
\text { night and early morning }\end{array}$ \\
\hline $\begin{array}{l}\text { Belville and Stewart } \\
(1983)^{* *}\end{array}$ & Louisiana & storm total $>200 \mathrm{~mm}$ & $\begin{array}{l}\text { cool season } \\
\quad \text { (October-May) }\end{array}$ & nocturnal (2000-1200 LST) \\
\hline $\begin{array}{l}\text { Giordano and } \\
\text { Fritsch (1983) }\end{array}$ & mid-Atlantic states & $190 \mathrm{~mm}$ in $\leqslant 12 \mathrm{~h}$ & $\begin{array}{l}\text { warm season } \\
\text { (May- } \\
\text { September) }\end{array}$ & early evening \\
\hline $\begin{array}{l}\text { Grice and Maddox } \\
\text { (1983) }\end{array}$ & south Texas & $\geqslant 127 \mathrm{~mm}$ in $\leqslant 24 \mathrm{~h}$ & N.A. & nocturnal \\
\hline $\begin{array}{l}\text { Fleming et al. } \\
\quad(1984)\end{array}$ & eastern U.S. & $\begin{array}{l}\text { flooding reported in } \\
\text { Storm Data }\end{array}$ & $\begin{array}{l}\text { warm season } \\
\text { (March- } \\
\text { October) }\end{array}$ & $\begin{array}{l}\text { most frequent between } 1600 \\
\text { and } 2000 \text { LST }\end{array}$ \\
\hline
\end{tabular}


TABLE 1. (Continued)

\begin{tabular}{|c|c|c|c|c|}
\hline Reference & Study area & Definition & Season & Diurnal characteristics \\
\hline $\begin{array}{l}\text { Landin and Bosart } \\
\text { (1985) }\end{array}$ & northeastern U.S. & $\begin{array}{l}>5 \mathrm{~mm} \mathrm{~h}^{-1} \\
>10 \mathrm{~mm} \mathrm{~h}^{-1}\end{array}$ & $\begin{array}{l}\text { winter } \\
\text { (November- } \\
\text { March), spring } \\
\text { (April-May), } \\
\text { summer (June- } \\
\text { August), fall } \\
\text { (September- } \\
\text { October) }\end{array}$ & $\begin{array}{l}\text { winter-0600-0800 LST; } \\
\text { spring, summer, fall-late } \\
\text { afternoon (approximately } \\
1800 \text { LST) }\end{array}$ \\
\hline Read (1985) & north Texas & $>127 \mathrm{~mm}$ in $\leqslant 24 \mathrm{~h}$ & $\begin{array}{l}\text { summer (June- } \\
\text { September) }\end{array}$ & $\begin{array}{l}\text { tropical events-no } \\
\text { preferred time; split } \\
\text { subtropical high events- } \\
\text { nocturnal; northwest flow } \\
\text { events-nocturnal }\end{array}$ \\
\hline Riley et al. 1987 & $\begin{array}{l}\text { Central Rockies } \\
\text { and Great Plains }\end{array}$ & $\begin{array}{l}>5 \mathrm{~mm} \mathrm{~h}^{-1} \\
>10 \mathrm{~mm} \mathrm{~h}^{-1}\end{array}$ & $\begin{array}{l}\text { summer (May- } \\
\text { August) }\end{array}$ & $\begin{array}{l}\text { approximately } 1800 \text { LST in } \\
\text { eastern Colorado and } \\
\text { Wyoming; approximately } \\
\text { 0000 LST in eastern } \\
\text { Kansas, Nebraska, and } \\
\text { South Dakota }\end{array}$ \\
\hline Winkler (1987) & eastern and central U.S. & $\begin{array}{l}6-12 \mathrm{~mm} \mathrm{~h}^{-1} \\
13-25 \mathrm{~mm} \mathrm{~h}^{-1} \\
26-40 \mathrm{~mm} \mathrm{~h}^{-1} \\
\geqslant 41 \mathrm{~mm} \mathrm{~h}^{-1}\end{array}$ & $\begin{array}{l}\text { summer (June- } \\
\text { August) }\end{array}$ & $\begin{array}{l}\text { nocturnal only in central } \\
\text { U.S.; elsewhere early to } \\
\text { late afternoon maximum }\end{array}$ \\
\hline Winkler (1988) & Minnesota & $\geqslant 76 \mathrm{~mm}$ in $\leqslant 24 \mathrm{~h}$ & $\begin{array}{l}\text { summer (June- } \\
\text { August) }\end{array}$ & $\begin{array}{l}\text { median time of onset- } \\
2100 \mathrm{LST}\end{array}$ \\
\hline
\end{tabular}

* Seasonality was not considered. Events from all months were included in the analysis.

† Ward's study was limited to extreme rainstorms associated with weakening tropical cyclones.

** Belville and Stewart only investigated extreme rainfall occurring with $500 \mathrm{mb}$ split flow.

time of maximum boundary-layer heating, other studies indicate that flood-producing rainstorms tend to be nocturnal in character. For example, Maddox et al. (1979), after examining over 150 flash floods that occurred in the eastern and central United States, concluded that extreme rainfall leading to flash floods in this area normally begins during the late evening and early morning hours. On the other hand, localized studies for Iowa (Wallace 1975), Illinois (Huff 1978; Changnon and Vogel 1980), Pennsylvania (Giordano and Fritsch 1983) and Appalachia (Guttman and Ezell 1980) found that excessive precipitation is most frequent in the late afternoon and early evening.

Factors contributing to these apparent discrepancies include the variety of definitions of a heavy rain event (see Table 1), the difficulty of assigning an event of several hours duration to a specific portion of the day, and the rarity of events of this magnitude and consequent small sample size for many of the studies. However, we propose that the conflicting results are in large part the result of ignoring important seasonal and regional variations in the time of onset of extreme precipitation, and that a more complete documentation of the diurnal characteristics of intense hourly precipitation should provide insight on the significance of these factors. We acknowledge that while flash flooding usually develops from sustained rainfall of several hours duration, the hourly precipitation amounts included in this analysis can either result from short, intense precipitation episodes or can represent a portion of a longer duration event. Nevertheless, the diurnal characteristics of intense hourly precipitation rates should approximate those of sustained extreme events, particularly as the heaviest precipitation rates associated with convective systems normally occur early in the storm's life cycle soon after the time of onset (McAnelley and Cotton 1986). An important advantage of using hourly rates to describe the time of onset of extreme rain events is that it is considerably easier to assign hourly rates rather than accumulated precipitation totals to a specific period of the day (i.e., early morning, late morning, . . . , late evening).

\section{Data and methodology}

Hourly precipitation measurements for the coterminous United States during the 17-year period $1967-$ 83 , were used to describe the diurnal characteristics of heavy hourly precipitation. Traditionally, the diurnal characteristics of precipitation have been identified from precipitation time series at a number of stations (Wallace 1975; Schwartz and Bosart 1979; Balling 1985; Landin and Bosart 1985; Riley et al. 1987). Because of the large spatial and temporal scales of this 
project, the use of station time series was not feasible. Instead, the methodology employed earlier by Winkler (1987) was used, whereby reporting stations first were located within the $75 \mathrm{~km} \times 75 \mathrm{~km}$ grid network utilized by the National Weather Service's objective heavy precipitation forecast system (Charba 1987). From all the observations falling within a given grid cell, only the maximum value reported during any hour of the 17 . year period was retained for analysis. Thus, the resulting time series for each grid cell were composed of the largest precipitation total recorded anywhere within that cell, during each hour of the 17-year period. The use of maximum precipitation amounts per grid cell instead of station totals meant that station histories did not have to be considered. Following the station history of the over 3000 stations used in the analysis would have been extremely unwieldy. Also, this methodology allowed all available hourly precipitation data to be utilized, including reports from stations with short periods of record or with several location changes. The fine mesh $(75 \mathrm{~km} \times 75 \mathrm{~km})$ grid initially was chosen in order to retain some sensitivity to local variations in precipitation occurrence.

Heavy hourly precipitation is defined here as precipitation rates of $2.5-6.2 \mathrm{~mm} \mathrm{~h}^{-1}\left(0.10-0.24\right.$ in h$\left.^{-1}\right)$, $6.3-12.6 \mathrm{~mm} \mathrm{~h}^{-1}\left(0.25-0.49\right.$ in h$\left.^{-1}\right), 12.7-25.3 \mathrm{~mm}$ $\mathrm{h}^{-1}\left(0.50-0.99\right.$ in $\left.\mathrm{h}^{-1}\right)$, and $\geqslant 25.4 \mathrm{~mm} \mathrm{~h}^{-1}(\geqslant 1.00$ in $\mathrm{h}^{-1}$ ). For convenience, these hourly rates will be referred to as precipitation categories 1-4 (Table 2). The precipitation time series for each grid cell were stratified according to the four precipitation rates, and hourly frequencies per category were determined for winter (December-February), spring (March-May), summer (June-August), and autumn (September-November).

Examination of the frequency distributions for the individual cells indicated that in many areas the number of precipitation events per hour was too small to describe the diurnal cycle accurately, particularly during the winter and spring seasons. Consequently, the frequency data were accumulated over $4 \times 4$ grid cell $(300 \mathrm{~km} \times 300 \mathrm{~km})$ areas in order to obtain a sufficient number of events for further analysis. For consistency, the same size accumulation region was used for all precipitation rates and seasons. The $4 \times 4$ grid cell areas, hereafter referred to as "analysis units," overlap by two grid cells in the north-south and east-west directions. Accumulating the frequency data over a number of grid cells effectively removed local variations in the

TABLE 2. Definition of precipitation categories.

\begin{tabular}{cc}
\hline & $\begin{array}{c}\text { Precipitation rate } \\
\left(\mathrm{mm} \mathrm{h}^{-1}\right)\end{array}$ \\
\hline Category & $2.5-6.2$ \\
1 & $6.3-12.6$ \\
2 & $12.7-25.3$ \\
4 & $\geqslant 25.4$ \\
\hline
\end{tabular}

diurnal cycle from the analysis, thereby limiting the study to a description of the regional variations in the diurnal characteristics of heavy hourly precipitation. To further insure that the number of events was sufficient for a reliable description of the diurnal cycle, only analysis units where the total number of events for a particular category and season was $\geqslant 48$ (mean number of events per hour $\geqslant 2$ ) were included in the analysis. This is a fairly lenient criterion compared to criteria employed in diurnal studies of tornadoes (Skaggs 1969; 72 events), hail (Skaggs 1980; 98 observations) and light and moderate precipitation (Wallace 1975; 200 events). The smaller, 48-event criterion was used because of the rarity of the precipitation events under study.

Diurnal variations were assessed through harmonic analysis of the hourly frequency data for each precipitation category and season. The normalized amplitude, defined as the amplitude divided by the 24-hour mean frequency of the event, and phase of the first (diurnal) and second (semidiurnal) harmonic were plotted in vector format (Wallace 1975), with the vector positioned at the midpoint of each analysis unit.

\section{The diurnal cycle of heavy hourly precipitation}

The vector plots of the phase and normalized amplitude of the first harmonic (Figs. 1-4) reveal that across much of the United States the diurnal cycle of heavy hourly precipitation varies significantly with season, geographic region, and precipitation intensity.

\section{a. Seasonal variations}

\section{1) WINTER (DECEMBER-FEBRUARY)}

The diurnal cycle of hourly precipitation is weakest in winter (Fig. 1). Across most of the United States, a low-amplitude, late morning to noontime maximum is evident for category 1 precipitation events. The largest normalized amplitudes for precipitation events of this magnitude are found in the southern High Plains from northwestern Texas to western Kansas, where a noontime maximum prevails. Also, normalized amplitudes are relatively large in southeastern and central Texas, where category 1 events are most common from approximately 0600 to $0900 \mathrm{LST}$.

Normalized amplitudes are substantially larger for category 2 precipitation rates, except in the northeastern United States and along the central Gulf Coast and Pacific Coast. Significant shifts in the phase angle of the diurnal cycle with increasing intensity occur in the Southwest, where more intense wintertime precipitation has a midafternoon maximum in frequency. Also, a nocturnal maximum becomes apparent in a broad area extending from Minnesota to Ohio and southward to central Mississippi and Alabama. Normalized amplitudes continue to increase for category 3 and 4 events, although the larger amplitudes partly result 

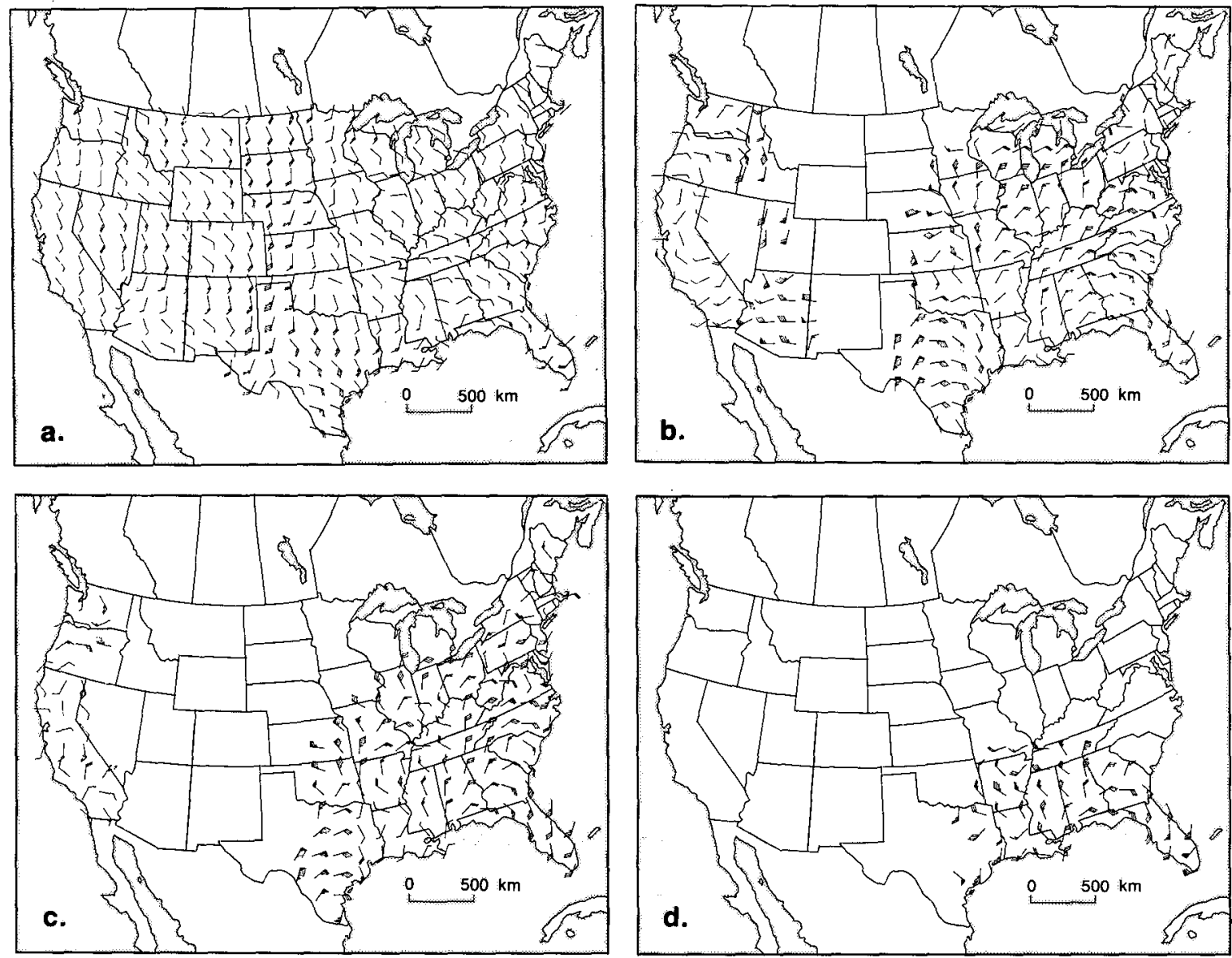

FIG. 1. Normalized amplitude and phase of the first harmonic during winter for precipitation rates of (a) $2.5-6.2 \mathrm{~mm} \mathrm{~h}^{-1}$ (category 1), (b) $6.3-12.6 \mathrm{~mm} \mathrm{~h}^{-1}$ (category 2), (c) 12.7-25.3 $\mathrm{mm} \mathrm{h}^{-1}$ (category 3) and (d) $\geqslant 25.4 \mathrm{~mm} \mathrm{~h}^{-1}$ (category 4). The number of analysis units for which values are plotted varies, as the harmonic analysis was performed only for units with at least 48 events for a particular category. An arrow directed from the north represents a phase angle of midnight LST, an arrow directed from the east indicates a 0600 LST maximum, etc. The normalized amplitude is represented by the flags and barbs on the arrows with each flag indicating a value of 0.5 , each full barb 0.10 , and each half barb 0.05 .

from the smaller number of events for these categories. The distribution of phase angles is more chaotic for the two largest precipitation rates, but, in general, a nocturnal or early morning maximum is evident in the central United States, the mid-Atlantic states, and much of the southeastern United States, whereas a noontime maximum is present in southern Florida.

\section{2) SPRING (MARCH-MAY)}

During the spring season (Fig. 2), the diurnal characteristics of category 1 amounts generally resemble those of wintertime events of the same magnitude. Over much of the United States, the normalized amplitudes are small and the phase angles specify a weak, late morning or noontime maximum in frequency. Notable differences between winter and spring include the disappearance in spring of the noontime maximum present during winter in the southern High Plains, the sig- nificant midafternoon maxima that become established during spring in southern Florida and the southwestern United States, and the springtime midday frequency maximum along the central Gulf Coast.

At most locations, springtime category $2-4$ precipitation rates are most frequent before midnight. In the Central Plains, the Great Lakes region, and the Ohio Valley, a late evening maximum (2000 to 0000 LST) prevails for the heavier hourly rates. Note that the phase of the diurnal cycle in this region shifts from one to two hours before midnight for category 2 events to three to four hours before midnight for category 3 and 4 amounts. In addition, the amplitude of the diurnal cycle increases significantly as precipitation intensity increases. Late afternoon maxima (approximately 1800 LST) predominate during spring in the Northeast and in the High Plains for the more intense precipitation rates. In the extreme southeastern United States, the Great Basin, and along the western slopes of the Rocky Mountains, the phase angles for category 2-4 events 

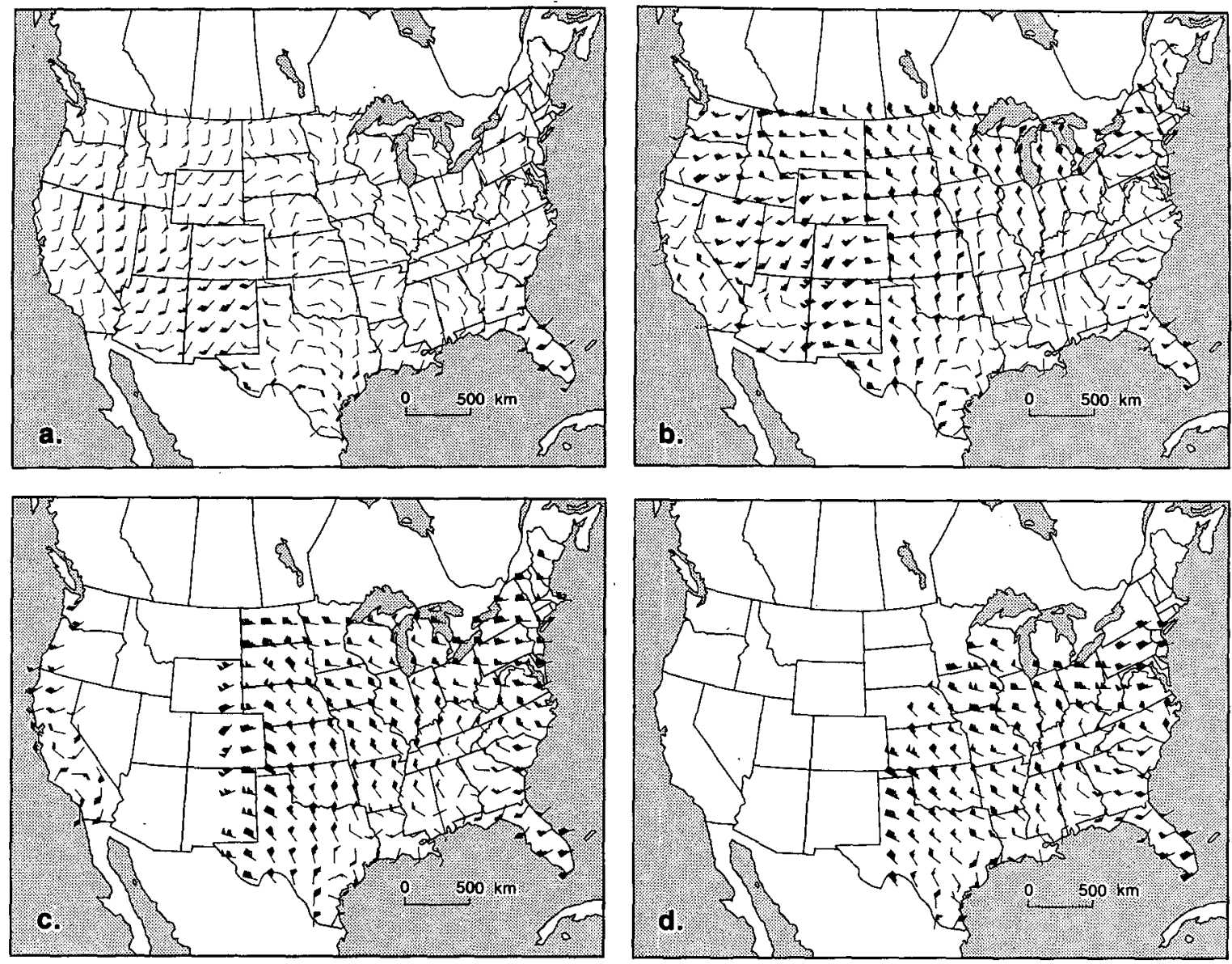

FIG. 2. As in Fig. 1 except for spring.

occur several hours earlier, around 1500 LST. Diurnal variations are small within a limited zone extending from southern Louisiana to eastern North Carolina. This zone appears to be a transition zone between the late evening precipitation regime of the central United States and the afternoon regime found in the extreme southeastern United States. The area encompassed by this transition zone decreases as precipitation rates increase. The diurnal cycle of heavy hourly precipitation also is weak during spring along the Pacific Coast.

\section{3) SUMMER (JUNE-AUGUST)}

The most striking feature of the vector plots of all four rainfall rates is the strong modulation of the diurnal cycle during summer, even for category 1 events (Fig. 3). Another major feature of the summer plots is the expansion of the region experiencing an early to late afternoon frequency maximum to include the entire East Coast, Appalachia, the Ohio Valley, and most of the Gulf Coast. At the same time, the nocturnal precipitation region of the central United States decreases in areal extent compared to winter and spring. As the nocturnal precipitation region contracts, the transition zone separating the afternoon and nocturnal rainfall regimes, where there is no preferred time of maximum frequency of heavy hourly precipitation, shifts considerably farther west of its springtime location and is now located from central Texas to southern Indiana. This transition zone becomes narrower as rainfall intensity increases, as is the case in spring. Another important seasonal variation is the consistently later phase angles in the Central Plains during summer. The nocturnal maximum occurs two to three hours later in the evening in summer compared to spring, although the aforementioned phase shift to earlier times with increasing precipitation intensity evident in the Central Plains during spring also is present in summer. In the western United States, the diurnal pattern becomes better organized during summer with a late afternoon maximum predominating along the eastern slopes of the Rocky Mountains and a midafternoon maximum evident west of the Continental Divide.

\section{4) AUTUMN (SEPTEMBER-NOVEMBER)}

The vector plot for autumn category 1 events (Fig. 4) is similar to the springtime plot for events of this 

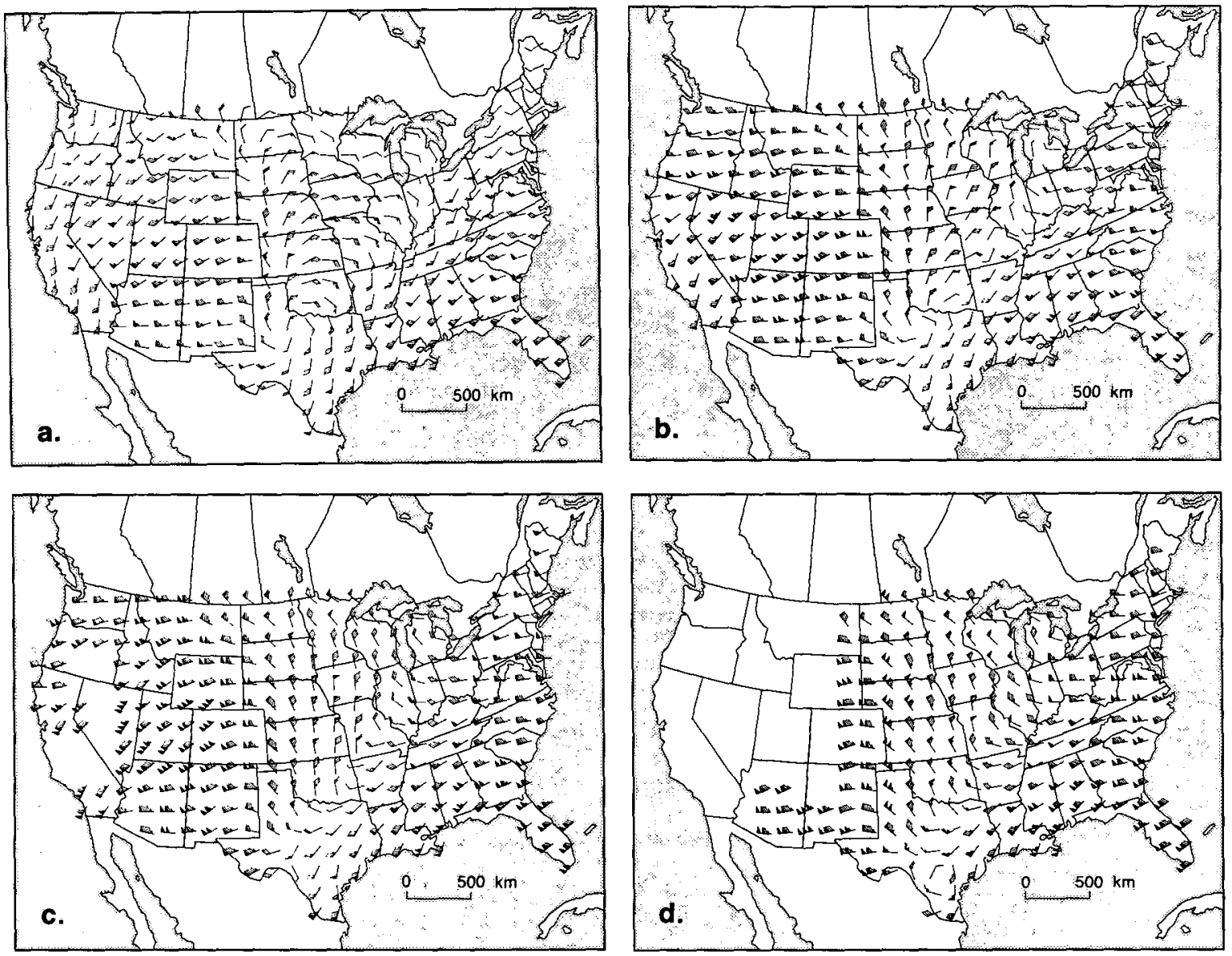

FIG. 3. As in Fig. 1 except for summer.

magnitude, except along the Gulf Coast where a near noon maximum is more pronounced in autumn than in spring. For category 2-4 rates, a nocturnal regime remains evident during autumn in the central United States. Generally, the autumn nocturnal region encompasses a larger area than the summertime nocturnal region but a smaller area than the spring region. Consequently, the transition zone between the afternoon and nocturnal precipitation regimes is located farther west in fall than in spring, and considerably east of the summer location. This generalization is complicated, however, by the nonuniform expansion of the nighttime precipitation region from summer to fall for the different precipitation categories. The area experiencing a nocturnal maximum during fall is largest, and therefore the transition zone is located farthest east, for category 2 events. On the other hand, the afternoon maximum of the eastern United States extends farther west for category 4 precipitation rates. Phase angles of the diurnal cycle in the nocturnal precipitation region during autumn resemble summertime values more closely than springtime phase angles. Similar to the spring and summer seasons, the phase angles shift to earlier in the evening and normalized amplitudes increase as precipitation rates increase. In the western United States, the diurnal cycle for category 2-4 amounts is generally weaker in autumn than in spring and summer.

\section{b. Regional variations in the seasonality of the diurnal cycle}

A notable feature of Figs. 1-4 is the significant spatial variation in the seasonality of the diurnal cycle of heavy hourly precipitation. While at some locations the diurnal phasing of intense hourly precipitation varies little from season to season, in other areas marked changes in the diurnal cycle with season occur. Harmonic dials for category 2 precipitation rates were prepared for several representative analysis units in order to better illustrate these regional variations in the seasonality of the diurnal cycle (Fig. 5). The analysis units for which harmonic dials were plotted are shown in Fig. 6.

Significant seasonal variations are found in the middle Atlantic region. The harmonic dial for Virginia (Fig. 5a) demonstrates that in this area there is no preferred time of maximum frequency during spring and autumn, while in summer a marked afternoon maximum 

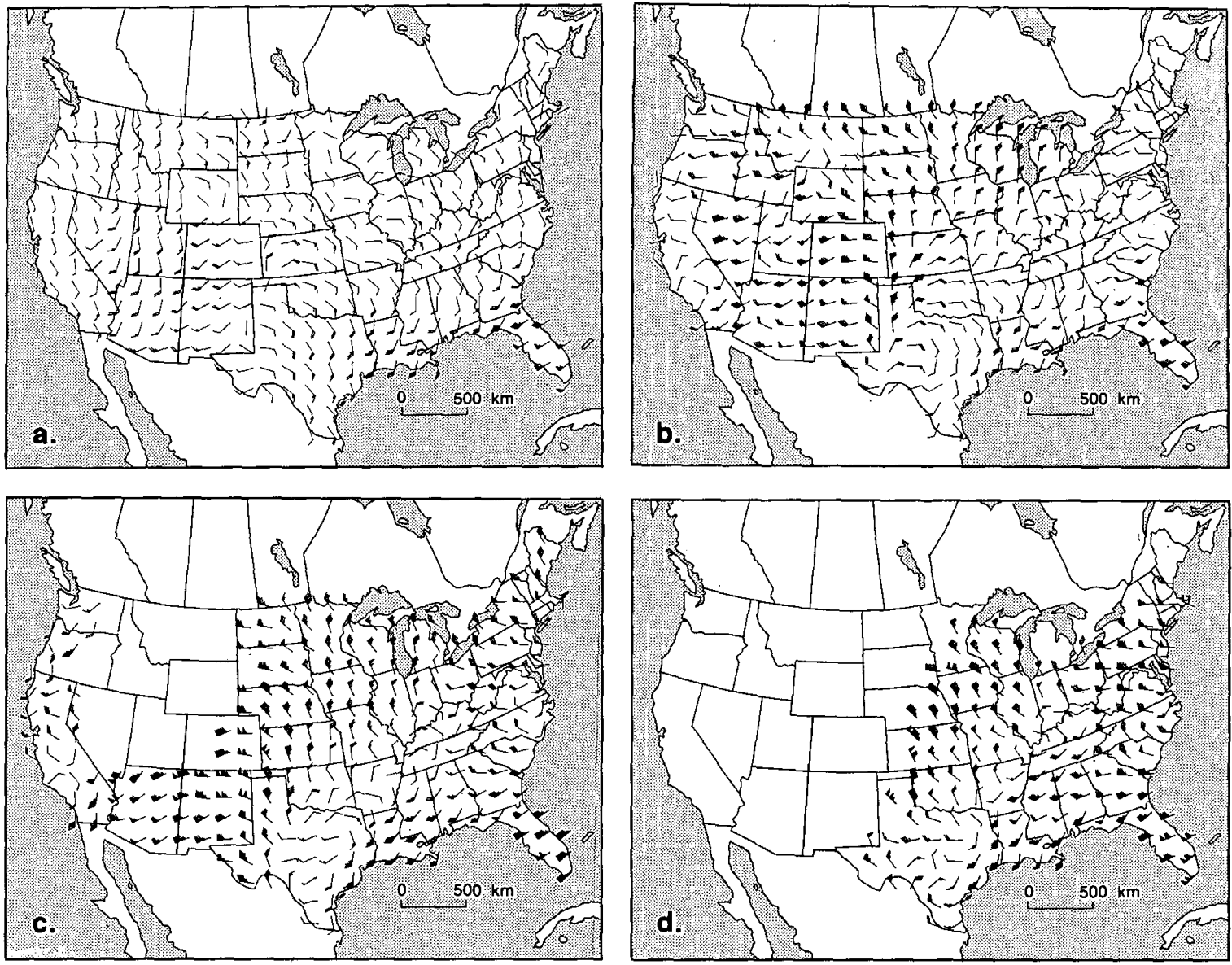

FIG. 4. As in Fig. 1 except for autumn.

is evident. During winter, a weak early morning maximum prevails. Farther north, seasonal changes in the diurnal cycle are small. Heavy hourly precipitation in the northeastern United States typically occurs between 1700 and $1800 \mathrm{LST}$, except in winter when intense precipitation is more uniformly distributed throughout the day (Fig. 5b).

Seasonal changes in the diurnal cycle of heavy hourly precipitation also are evident in the southeastern United States along the Gulf Coast. Strong midafternoon maxima in frequency are present along the eastern Gulf Coast during summer and autumn (Fig. 5c). In spring, a weak afternoon maximum is present, but in winter the afternoon maximum evident during the other three seasons is replaced by a late morning to noontime maximum. Farther west, in southern Mississippi (Fig. 5d), a marked afternoon maximum is evident only during the summer season. In autumn, a noontime maximum is indicated, and in winter and spring heavy hourly precipitation is more uniformly distributed throughout the day. Along the western Gulf Coast in southeastern Texas (Fig. 5e), late morning or noontime maxima are present during all seasons, al- though the midday maximum is most pronounced during the summer season.

The seasonal shifts of the transition zone separating the eastern afternoon precipitation regime from the nocturnal regime of the central United States are demonstrated by the harmonic dial for northern Alabama (Fig. 5f). In spring and autumn; this area lies within the transition zone. However, during winter this location falls within the nocturnal regime, while in summer it is located within the afternoon precipitation region.

In much of the central United States, heavy hourly precipitation is nocturnal during all seasons. The harmonic dial for Iowa (Fig. $5 \mathrm{~g}$ ) indicates that the nocturnal maximum is considerably more pronounced in summer than at other times of the year. Note also that the phase of the diurnal cycle occurs later in the evening in summer compared to the other seasons. In northern South Dakota (Fig. 5h), which is located at the edge of the nocturnal region, the time of maximum frequency of heavy hourly precipitation occurs in the late afternoon and early evening during spring and autumn. Summertime precipitation is more nocturnal in char- 
a. Northern Virginia

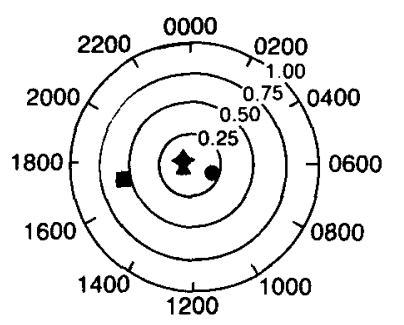

d. Southern Mississippi

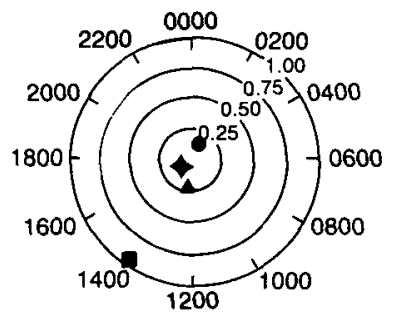

g. Lowa

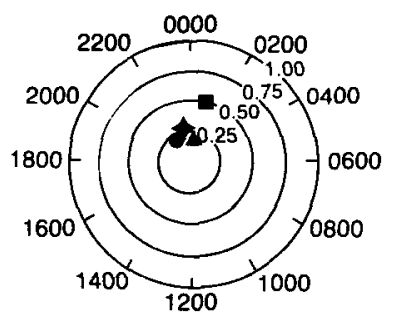

j. Central Utah

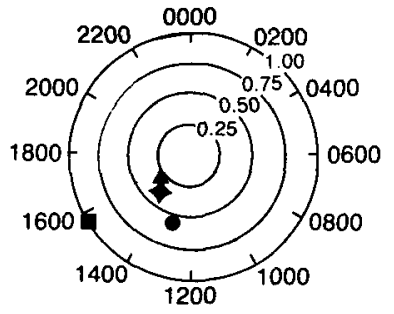

- Winter b. Eastern New York

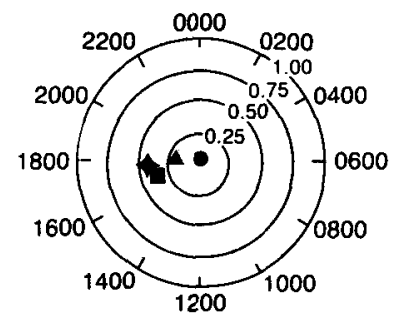

e. Southeastern Texas

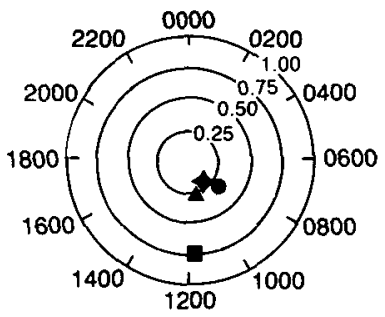

h. South Dakota

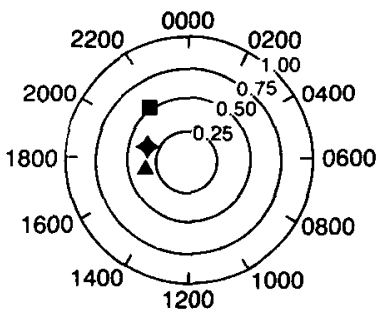

k. Southern California

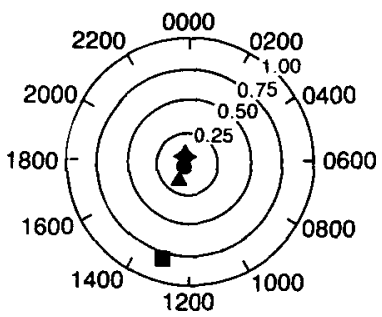

c. Western Florida

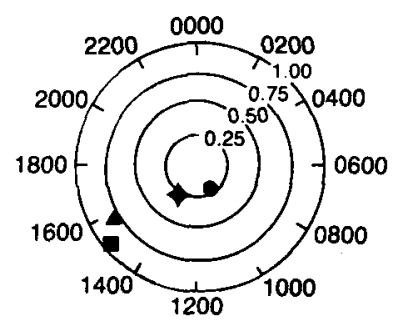

f. Northern Alabama

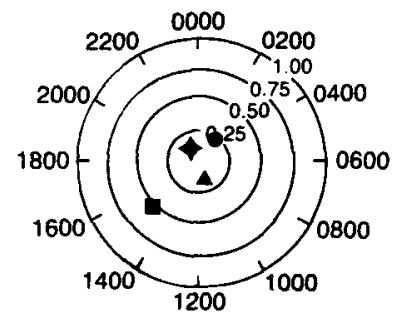

i. Central Texas

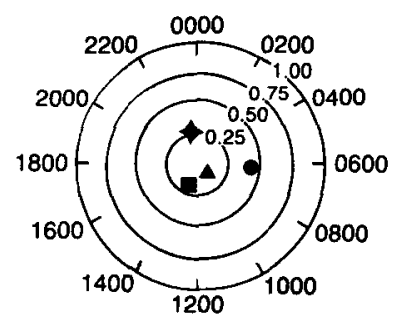

I. Oregon

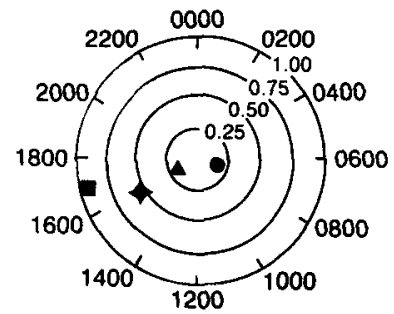

A - Fall

FIG. 5. Harmonic dials showing the phase of the diurnal cycle (LST) and normalized amplitude for precipitation rates of 6.3-12.6 $\mathrm{mm} \mathrm{h}^{-1}$ (category 2) during winter, spring, summer, and autumn for representative analysis units. Refer to Fig. 6 for locations.

acter, although the phase occurs considerably earlier in the evening than summertime phase angles in Iowa.

Large changes in the diurnal cycle with season are found in central Texas (Fig. 5i). During winter, heavy hourly precipitation is most frequent in the early morning hours between approximately 0200 and 0600 LST. Springtime heavy precipitation also is nocturnal, although the time of maximum frequency occurs sev- 


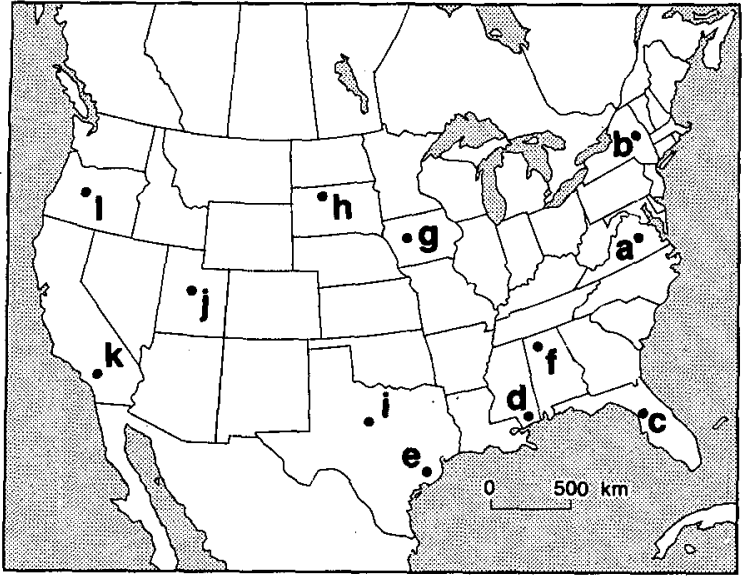

FIG. 6. Locations of analysis units for which harmonic dials are presented in Fig. 5.

eral hours earlier, near midnight. On the other hand, weak, early afternoon maxima are present in summer and autumn.

Seasonal variations in the diurnal cycle of intense hourly precipitation in the western United States are represented by the harmonic dials for central Utah, southern California, and western Oregon. In the Great Basin the diurnal cycle varies little with season (Fig. $5 \mathrm{j})$. Intense precipitation is most prevalent in the midafternoon during spring, summer, and autumn. During winter a noontime maximum is evident, although heavy precipitation occurs infrequently at this time of year. Seasonal variations also are small in southern California, where heavy hourly precipitation is uniformly distributed throughout the day, except during the summer season when an early afternoon maximum prevails (Fig. 5k). Farther north in Oregon, pronounced late afternoon maxima are evident in spring and summer, whereas a weak afternoon maximum is present in autumn (Fig. 51). Heavy hourly precipitation in the Pacific Northwest during the winter season is equally likely at all times of the day.

\section{c. Variations in the diurnal cycle with precipitation in- tensity}

Also evident from Figs. 1-4 are the significant changes in the amplitude and phase angle of the diurnal cycle as hourly precipitation intensity increases. During all seasons, the amplitude of the first harmonic increases substantially with increasing precipitation intensity at most locations in the coterminous United States. These increases imply that precipitation becomes confined to a smaller portion of the day as intensity increases.

Changes in the phase angle of the first harmonic with increasing precipitation intensity are more complex than the amplitude changes. To illustrate the phase shifts, the percentage of analysis units with phase angles during each hour of the day were plotted for the first three precipitation categories. Figure 7 shows the large shift in the phase angle of the first harmonic between precipitation categories 1 and 2 . Generally, across the
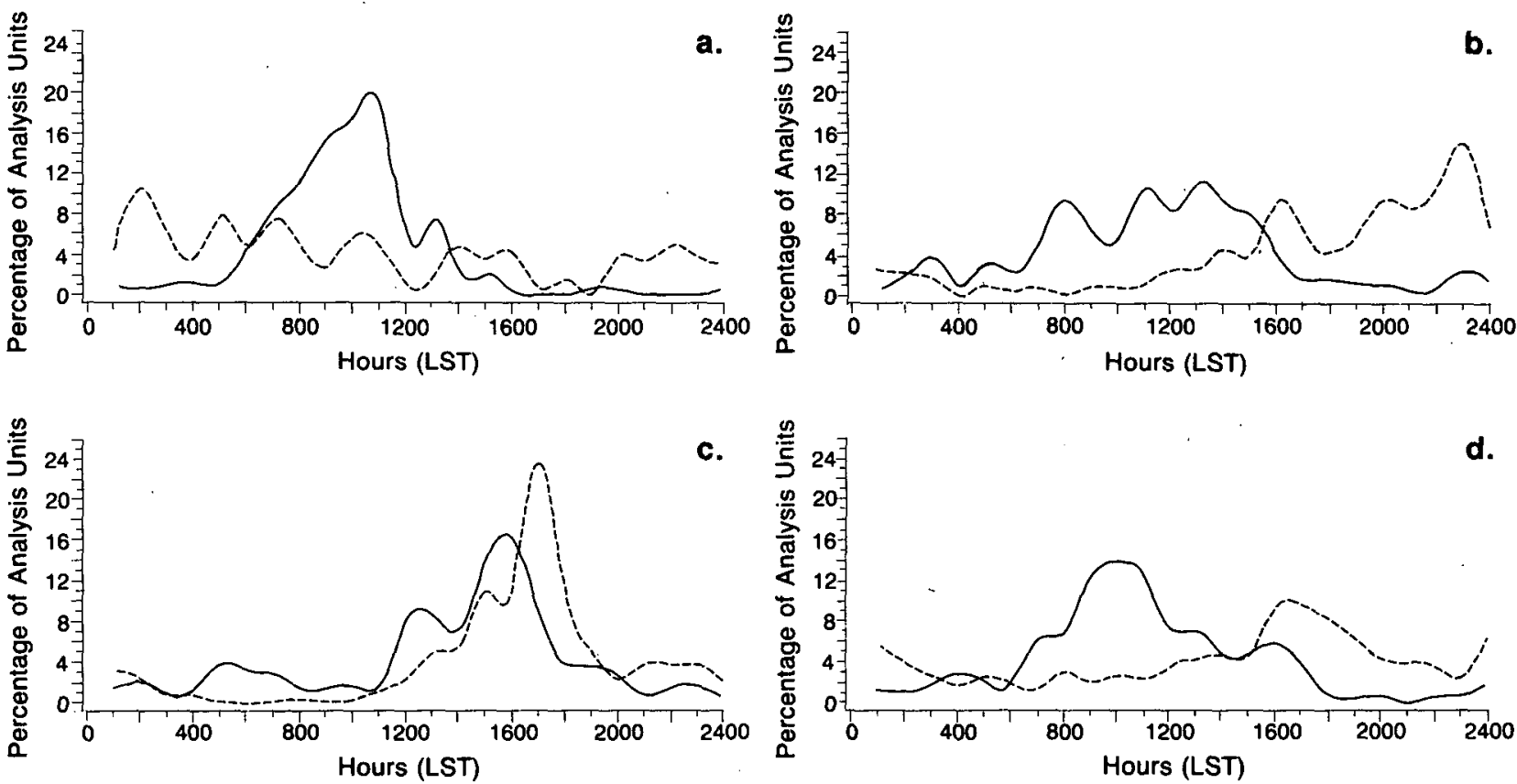

FIG. 7. Phase angle of the first harmonic (in LST) during (a) winter, (b) spring, (c) summer, and (d) autumn for precipitation rates of 2.5-6.2 $\mathrm{mm} \mathrm{h}^{-1}$ (category 1), solid line, and 6.3-12.6 $\mathrm{mm} \mathrm{h}^{-1}$ (category 2), dashed line. 
United States the time of maximum frequency of category 1 events precedes that of category 2 events, especially during spring and autumn when the lead time is six hours or greater. Even in summer when the occurrence of both light and heavy hourly precipitation is strongly modulated by the diurnal heating cycle, category 1 amounts are most frequent several hours earlier than category 2 amounts. The relationship between the phase angle and precipitation intensity is more ambiguous in winter when the phase angles for category 2 events are distributed more uniformly throughout the day.

Similar shifts in the phase angle of the first harmonic with increasing intensity are not evident between categories 2 and 3 (Fig. 8) and between categories 3 and 4 (not shown). The phase angle distributions for the three largest precipitation categories are remarkably similar during all seasons. Figures $1-4$ also suggest that while there are large shifts in the phase angle between categories 1 and 2 at most locations, the phase angles for categories 2-4 are similar. The only exception to this generalization is the central United States, where during all seasons precipitation occurs earlier in the evening as rainfall intensity increases.

A possible explanation for the significant differences in the diurnal cycles between category 1 and category 2-4 rates is that different physical processes are responsible for lighter precipitation events than for heavier hourly amounts. Alternatively, the differing diurnal characteristics suggest that a progressively smaller number of synoptic and mesoscale circulation patterns are responsible for intense hourly precipita- tion, and that these circulation patterns have distinct diurnal fluctuations. A comparison of the diurnal characteristics presented here for category 1 rates with those of lighter (trace and $\geqslant 0.25 \mathrm{~mm} \mathrm{~h}^{-1}$ ) precipitation amounts presented elsewhere (Wallace 1975; Mass 1982; Balling 1985; Landin and Bosart 1985; Riley et al. 1987) reveals that the diurnal variability of category 1 events is more similar to that of light precipitation rates than to that of intense (category 2-4) hourly precipitation. Therefore, category 1 precipitation rates perhaps should be considered a "light" or "moderate" precipitation event rather than a "heavy" event. A better definition of a "heavy" event would be an hourly rate of $>5$ or $>6 \mathrm{~mm} \mathrm{~h}^{-1}$.

\section{The semidiurnal cycle of heavy hourly precipitation}

The normalized amplitude and the phase of the first maximum of the second harmonic for the different seasons and precipitation categories also were plotted in order to determine whether secondary maxima and minima in the diurnal cycle of hourly precipitation are present (Figs. 9 and 10). As pointed out by Wallace (1975), interpretation of the second harmonic often is ambiguous, since this harmonic either can represent true secondary maxima and minima or can be a mathematical artifact of fitting a periodic function to a nonsinusoidal frequency distribution. Wherever the frequency distributions are extremely peaked (i.e., normalized amplitude of the first harmonic is close to unity), the second harmonic reinforces the maximum and smooths the trough of the diurnal cycle. At these
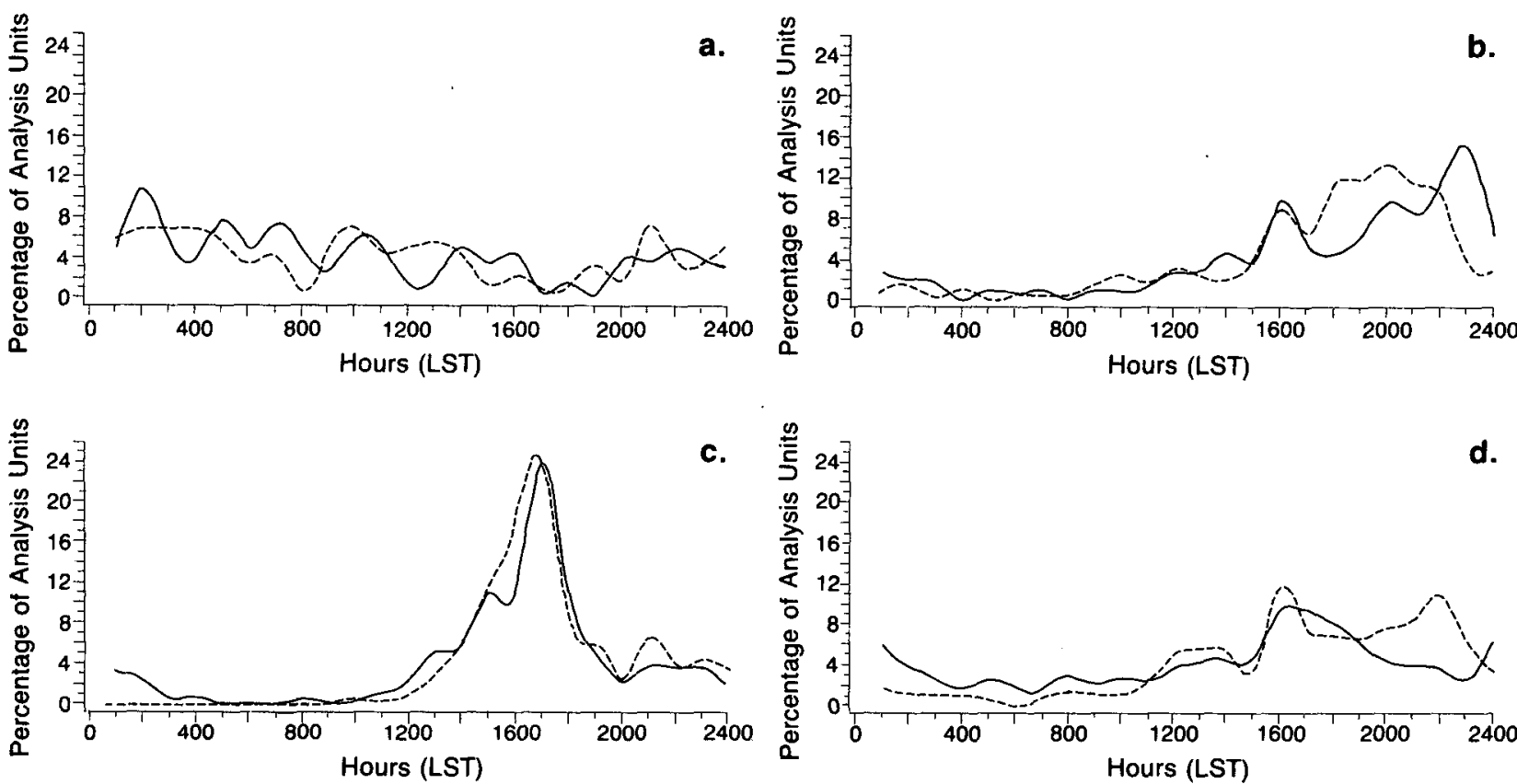

FIG. 8. As in Fig. 7 except for precipitation rates of 6.3-12.6 $\mathrm{mm} \mathrm{h}^{-1}$ (category 2), solid line, and $12.7-25.3 \mathrm{~mm} \mathrm{~h}^{-1}$ (category 3 ), dashed line. 

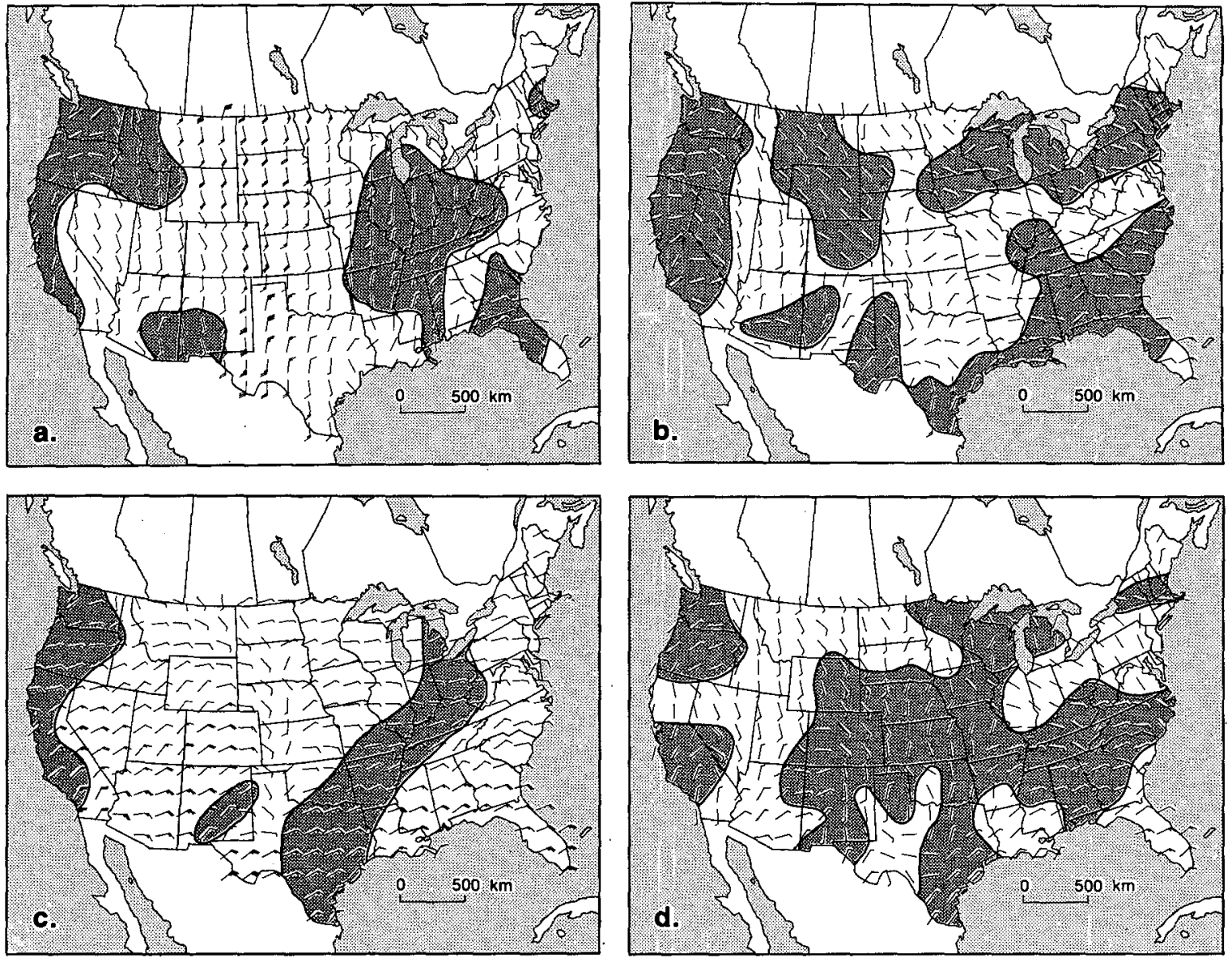

FIG. 9. Normalized amplitude and first maximum of the second harmonic for precipitation rates of $2.5-6.2 \mathrm{~mm} \mathrm{~h}^{-1}$ (category 1) during (a) winter, (b) spring, (c) summer, and (d) autumn. The second maximum of the semidiurnal cycle occurs 12 hours later than the first maximum. Shading indicates regions where the difference in phase angles between the first and second harmonics is $>2$ hours.

locations, the first and second harmonics usually are in phase. More confidence can be placed in semidiurnal oscillations at locations where there is a substantial difference in the phase angles of the first and second harmonics (Skaggs 1969). In order to identify more easily important semidiurnal fluctuations, areas where the differences between the phase angles of the first harmonic and either the first or second maximum of the second harmonic, whichever appropriate, are $>2$ hours are shaded in Figs. 9 and 10.

At almost all locations the amplitude of the first harmonic for all four precipitation categories during spring, summer, and autumn greatly exceeds that of the second harmonic. Only in winter, when the diurnal cycle of intense hourly precipitation is weakest, are the amplitudes of the two harmonics comparable. Significant semidiurnal oscillations are evident at only a few locations for category 1 precipitation rates (Fig. 9). During spring and autumn, the first and second harmonics are out of phase over a large portion of the United States, but the normalized amplitudes of the second harmonic are extremely small $(\leqslant 0.05)$. An exception is southeastern Texas in spring, where secondary maxima are evident at approximately 0100 and 1300 LST. Also, secondary maxima are present in the High Plains during autumn at approximately 0900 and 2100 LST. The harmonics are out of phase during summer in the transition region separating the nocturnal and afternoon precipitation regimes, although relatively large $(>0.10)$ amplitudes of the second harmonic are found only in eastern and central Texas (0400 and 1600 LST maxima). Secondary maxima also are present in central Texas during winter. At this time of year, however, the maxima occur several hours earlier (0100 and 1300 LST) compared to summer.

Semidiurnal oscillations are apparent at a larger number of locations for category 2 rates (Fig. 10) and for category 3 and 4 rates (not shown). Along the southern Great Lakes from eastern Indiana across Ohio southward to northern Kentucky, secondary maxima of heavy hourly precipitation are evident during all seasons except summer. In both winter and spring, 

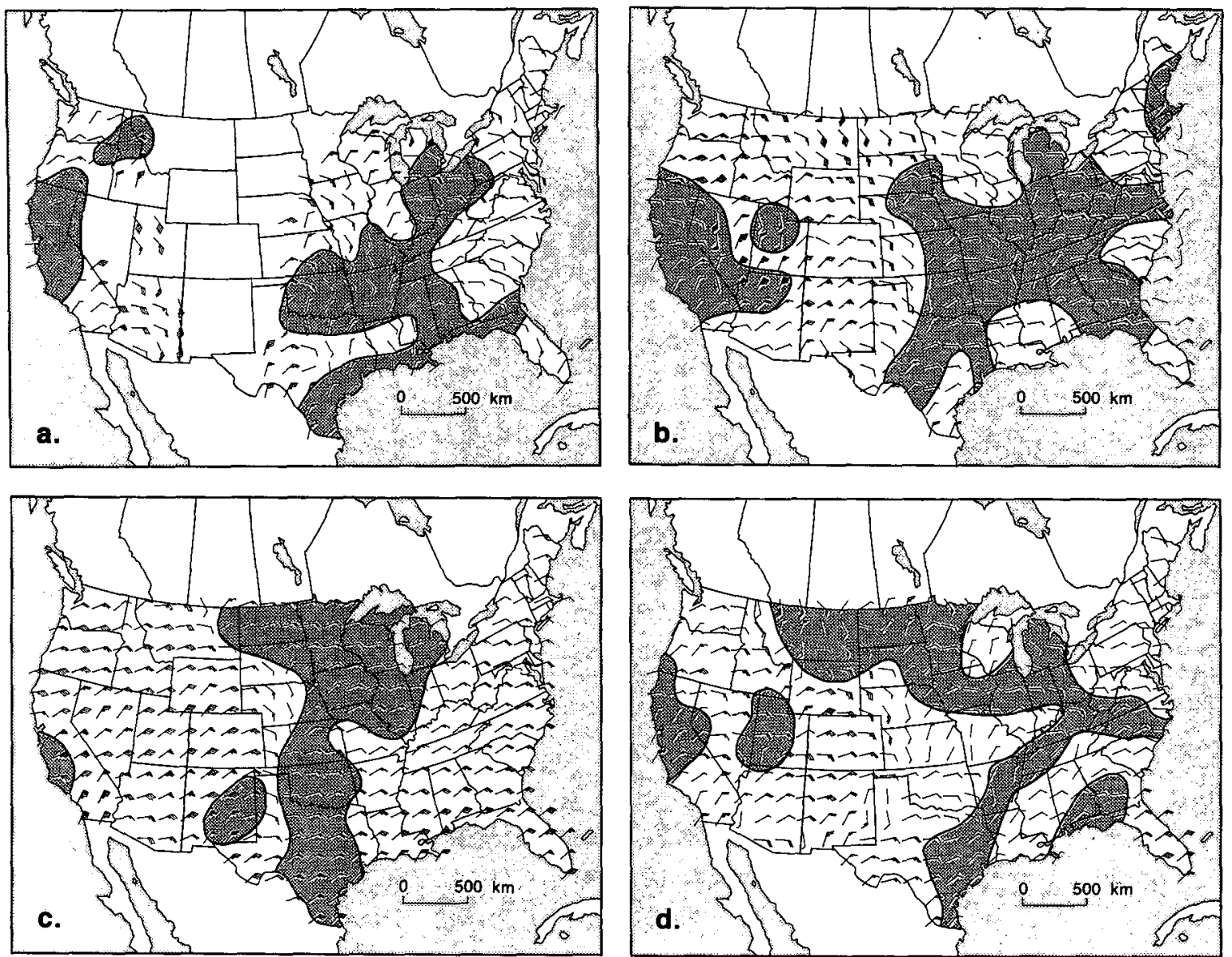

FIG. 10. As in Fig. 9 except for precipitation rates of $6.3-12.6 \mathrm{~mm} \mathrm{~h}^{-1}$ (category 2).

0600-1800 LST maxima prevail, while the fall maxima occur slightly later at approximately 0700 and 1900 LST. In central Texas, significant semidiurnal fluctuations (0400-1600 LST maxima) for the three largest precipitation rates are evident only in summer. The semidiurnal oscillation present during winter in central Texas for category 1 rates is not evident for category 2-4 events. In southeastern Texas, significant semidiurnal oscillations for category 2-4 events are present during winter and autumn. For both seasons, the maxima occur around 0300-1500 LST. In addition, semidiurnal oscillations centered around 0500 and 1700 LST are found in northern Florida and southern Georgia in spring. Along the West Coast, secondary maxima are evident during winter in northwest Oregon (04001600 LST maxima), and in central California during spring (0200-1400 maxima) and fall (0300-1500 maxima).

\section{Relations to previous work}

A comparison of the results of this investigation to those of earlier studies provides useful insights on the significance of the seasonal and spatial variations of the diurnal characteristics of heavy precipitation. As discussed previously, a number of studies have used harmonic analysis to describe the diurnal fluctuations of precipitation. For the most part, these studies have dealt only with light and moderate precipitation amounts. The diurnal patterns presented here for category 1 rain intensities during summer closely resemble patterns published elsewhere for events of $\geqslant 2.5 \mathrm{~mm}$ $\mathrm{h}^{-1}$ in the eastern and central United States (Wallace 1975), the Great Plains/Rocky Mountain region (Balling 1985; Riley et al. 1987), and Florida (Schwartz and Bosart 1979). Minor differences include the earlier phase angles identified by Riley et al. (1987) in eastern Nebraska and Kansas and the more pronounced summertime nocturnal maximum along Lake Michigan identified by Wallace (1975). In addition, the normalized amplitude and phase values in New England and the Great Plains/Rocky Mountain region for the larger (category 2-4) summertime precipitation rates are almost identical to values provided by Landin and Bosart (1985) and Riley et al. (1987) for summertime events of $>5 \mathrm{~mm} \mathrm{~h}^{-1}$ and $>10 \mathrm{~mm} \mathrm{~h}^{-1}$ in these regions. 
Wintertime diurnal fluctuations, on the other hand, differ considerably from previously published results. These discrepancies largely appear to be the consequence of the different definitions of "winter" employed in previous studies. Wallace, who defined the winter season as November-March, identified a significant nocturnal maximum for wintertime precipitation events of $\geqslant 2.5 \mathrm{~mm} \mathrm{~h}^{-1}$ in much of the eastern and northern United States. In contrast, a weak, late morning maximum is evident in Fig. 1a for this area. Landin and Bosart (1985) also defined winter as extending from November-March, and their vector plot for wintertime events of $\geqslant 2.5 \mathrm{~mm} \mathrm{~h}^{-1}$ in the northeastern United States initially appears to differ from the wintertime diurnal cycle identified in this study for the Northeast. However, a comparison of the vector plots provided by Landin and Bosart for early winter (November-December) and late winter (JanuaryMarch) reveals that the diurnal cycle of early winter precipitation is similar to the diurnal pattern presented here for December-February events, while the late winter diurnal cycle more closely resembles the wintertime characteristics identified by Wallace (1975) for November-March. Landin and Bosart attributed the marked change in the diurnal cycle for events of $\geqslant 2.5$ $\mathrm{mm} \mathrm{h}^{-1}$ to the impact of the colder and partially frozen Great Lakes from midwinter to early spring.

Another region where the diurnal characteristics of wintertime precipitation totals of $\geqslant 2.5 \mathrm{~mm} \mathrm{~h}^{-1}$ presented elsewhere differ from those identified here is the Great Plains/Rocky Mountain region. Riley et al. (1987), who defined winter as November-February, indicate that a marked 0300 LST frequency maximum and a weaker 0900 LST maximum prevail in this region during winter, whereas only an approximately 0900 LST frequency maximum is evident from Fig. 1a. Only in Florida do the diurnal characteristics of wintertime precipitation closely agree with those published in an earlier study (Schwartz and Bosart 1979). Of the above studies, only that of Schwartz and Bosart employed the same definition of winter (December-February) as used in this investigation. Divergent findings for studies employing different seasonal definitions indicate that further research for shorter time periods, perhaps even at the monthly or bimonthly scale, is necessary in order to understand more completely the changes over the course of the year of the diurnal phasing of precipitation.

If the temporal distribution of heavy hourly precipitation rates is assumed to approximate that of longer duration events, then the results of this study indicate that the time of onset of flash flood-producing rainstorms also should vary with season and geographic region. Thus, the contradictory results of earlier studies may partly be the result of neglecting important seasonal and spatial variations in the diurnal cycle. Inspection of Table 1 suggests that studies limited to only a few months during summer (Changnon and Vogel
1980; Giordano and Fritsch 1983), a time when intense hourly precipitation across much of the United States is most frequent in the afternoon and early evening, also reported afternoon and early evening maxima for longer duration extreme rainstorms. On the other hand, investigations confined to winter, spring, or autumn or that combined extreme rain events from both the warm and cool seasons more often reported nocturnal precipitation maxima (Belville and Stewart 1983; Maddox et al. 1979). The results of this study suggest that the nocturnal precipitation region expands during the cool season to encompass much of the eastern and central United States.

\section{Physical interpretation}

Numerous authors previously have speculated on the possible dynamic and thermodynamic processes contributing to the diurnal variability of precipitation. In this section, the diurnal patterns of heavy hourly precipitation are interpreted in terms of several frequently postulated explanations for the diurnal phasing of precipitation. Discussion necessarily is limited to the influence of regional-scale circulation features, since the importance of local circulations, such as mountainvalley airflows, cannot be inferred from the vector plots due to the smoothing procedure applied to the frequency data.

Wallace (1975) attributed the pervasive, although weak, morning maximum of light and moderate precipitation across much of the eastern two-thirds of the United States in winter to a predominance of warm frontal precipitation events during this season. Diurnal enhancement of wintertime precipitation along warm frontal boundaries has been hypothesized to result from stronger boundary-layer winds above nighttime inversions in the warm sector of developing cyclones (Dexter 1944; Wallace 1975). The large area shown in this study to experience a morning maximum for wintertime category 1 events further indicates that synoptic-scale controls are largely responsible for the diurnal phasing of moderate precipitation events over much of the United States in winter. Note that there normally is a several hour lag between the approximately 0200 LST time of strongest boundary-layer winds (Hoxit 1975) and the time of greatest frequency of category 1 events. Nocturnal land breeze circulations very likely also contribute to the morning phasing of wintertime precipitation along the Great Lakes, as postulated by Passarelli and Braham (1981).

In several areas a morning frequency maximum for category 1 events is not evident. For example, wintertime precipitation is relatively uniformly distributed throughout the day in New England. A factor partly responsible for the smaller diurnal cycle is that in this region precipitation is associated with a number of different synoptic-scale circulation patterns. Wintertime precipitation frequently occurs along and in advance 
of warm frontal boundaries, and with this circulation pattern a morning frequency maximum would be expected. However, precipitation in New England also commonly occurs during winter west and northwest of offshore surface lows. Precipitation on the "backside" of low pressure systems is associated with easterly low-level flow (e.g., "the cold conveyor belt"; Carlson 1980), upper-level features (jet maxima and shortwave trough), and thermodynamic factors (cold air aloft) rather than with the diurnally oscillating low-level flow of the warm sector. An additional synoptic pattern that brings precipitation to New England is the passage of cold frontal boundaries associated with Canadian low pressure systems tracking along the St. Lawrence Valley. The time of occurrence of precipitation depends upon the timing of the frontal passage.

Marked changes in the diurnal phasing of wintertime precipitation occur across the Florida Peninsula, and these phase shifts generally can be related to the frequency of warm and cold frontal passages. Warm frontal passages are considerably more frequent in northern Florida, and as a consequence wintertime precipitation displays a morning maximum in this area. In southern Florida stronger diurnal heating of the boundary layer along with more frequent cold frontal passages contribute to an early afternoon maximum. Noontime phase angles found in the High Plains are difficult to interpret physically, but possibly result from the rarity of wintertime events of this magnitude and the consequent small number of events for the harmonic analysis calculations.

The diurnal pattern is more chaotic for wintertime category 2-4 precipitation events, but, in general, an earlier (approximately 0300-0600 LST) maximum becomes prevalent in the eastern and central United States compared to the 0600-1100 maximum present for category 1 events. This phase shift is especially evident in the Mississippi and Ohio Valley region. The nocturnal maximum for category 2-4 events suggests that heavy hourly precipitation in winter remains most frequent with warm frontal passages. However, as precipitation intensity increases, there is a better correspondence between the time of strongest low-level winds, and consequent strongest low-level convergence, and the time of maximum frequency of precipitation.

Exceptions to the early morning maximum for wintertime category 2-4 events include the previously discussed noon to early afternoon precipitation maximum present in southern Florida and the weak diurnal cycle in New England. In addition, a later (midafternoon) maximum is evident for category 2 events in the Southwest. Earlier research on flood episodes in the western United States (Maddox et al. 1980) has shown that the majority of very heavy rain events in the this area occur during the late afternoon, suggesting that these events are closely tied to the diurnal heating cycle.

Springtime precipitation in much of the United States normally is associated with strong synoptic-scale weather systems. The nocturnal maximum identified in this study for springtime heavy precipitation in the Great Plains supports the findings of Astling et al. (1985) that, although large-scale synoptic flow patterns produce favorable conditions for heavy precipitation during both day and night, in the Great Plains a nocturnal cycle of precipitation often is associated with these systems. They concluded that the nocturnal convection arises from boundary-layer convergence and subsequent rising motion ahead of a nocturnally enhanced low-level jet. The vector plots presented here for category 2-4 events suggest that this nocturnal oscillation of precipitation associated with synoptic-scale systems not only occurs in the Great Plains but also extends eastward into the north central and Great Lakes states. The afternoon frequency maximum over much of the western United States in spring and the stronger diurnal modulation of precipitation in this area broadly can be related to heating of elevated terrain (Reiter and Tang 1984).

A counterclockwise shift in phase angle with increasing precipitation intensity is evident in the central United States during spring. In the southern Plains this phase shift may, in part, be correlated to the life cycle of mesoscale convective complexes (MCCs) as defined by Maddox (1980). Intense rainfall associated with MCCs is most likely close to the time the complexes reach their maximum extent, typically around local midnight (Maddox et al. 1986). MCCs are common in the southern Plains in late spring (e.g., see Maddox et al. 1986, Fig. 17.2) and quite likely are responsible for the heaviest rainfall intensities reported at this time of year. The typical life cycle of MCCs cannot be used to explain the phase shift in the northern Plains, as MCCs are infrequent during spring in this region. Here the phase shift may result from a greater influence of thermodynamic processes, as suggested by Wallace (1975).

During summer, diurnal boundary-layer heating significantly contributes to the initiation and/or intensification of heavy convective precipitation, as would be expected. Well-defined afternoon maxima prevail over the western United States and most of the East Coast, for all four precipitation categories. The effect of latitude on the strength and timing of the boundarylayer heating cycle is evident from the earlier (approximately 1500 LST) phase angles in the Southwest and Southeast in comparison to the late afternoon (approximately 1800 LST) phase angles found farther north in the middle Atlantic states, the Ohio Valley, and the Northeast.

Striking exceptions to the summertime afternoon maximum are the nocturnal precipitation region of the central United States and the midday maximum along the western Gulf Coast. The progressively later phase angles from the High Plains to approximately $100^{\circ} \mathrm{W}$ suggest that convective systems in this area initiate along the foothills and Front Range of the Rocky Mountains and drift eastward, perhaps in response to 
the eastward propagation of nocturnal downslope surface flows (Wetzel et al. 1983; Reiter and Tang 1984; Toth and Johnson 1985). More uniform phase angles east of $100^{\circ} \mathrm{W}$, particularly for category 2-4 intensities, lead us to concur with Riley et al. (1987) that intense precipitation across the eastern Plains cannot be accounted for solely by the eastward advection of convective systems that formed the previous afternoon along the eastern slopes of the Rocky Mountains. While these mountain-generated systems contribute to the precipitation climatology of the central and eastern Plains, locally generated nocturnal systems appear to be equally important. Additional support for this contention is provided by Maddox et al. (1986), who found that nearly one-half of the MCCs that formed during 1978-82 initiated between $90^{\circ}$ and $100^{\circ} \mathrm{W}$. Thermodynamic and dynamic processes that have been linked to nocturnal convection include a nocturnally enhanced low-level wind maximum (Pitchford and London 1962; Bonner 1968), nighttime large-scale drainage into the Plains (Holton 1967), and differential radiational cooling between cloud systems and surrounding cloud-free regions (Gray and Jacobson 1977).

Along the Gulf Coast, the time of maximum frequency of summertime heavy hourly precipitation varies from one to two hours before noon in southeastern Texas to two or more hours after noon in the Florida panhandle. Larger amplitudes for the semidiurnal cycle in southeastern Texas suggest that two maxima, a late morning maximum and an early afternoon maximum, are present during summer. We hypothesize that the morning convective activity along the Gulf Coast of Texas originally forms at night along the convergence zone of the land breeze circulation and the regional-scale airflow. As the land breeze weakens during the morning hours, the storms drift onshore with the prevailing southeasterly surface flow. On the other hand, the afternoon maximum occurs close to the time of greatest boundary-layer heating. Morning convection also occurs farther east in southern Louisiana, Mississippi, Alabama, and northwestern Florida, but is less frequent because regional-scale surface airflow often has an offshore component during summer. Blanchard and Lopez (1985) have shown that in southern Florida convection begins earlier on days when the surface airflow has a southwesterly component compared to days with southeasterly and easterly airflow.

The marked change in the diurnal phasing of category 2-4 precipitation events from spring to summer in central and northern Texas can partly be explained by the decrease in frequency of MCC occurrences. During spring when these nocturnal storm systems are most frequent, heavy hourly precipitation displays a nocturnal maximum. Midafternoon convection often is suppressed in this region during spring by the occurrence of elevated mixed layers or lids (Carlson et al. 1983). MCCs rarely occur in central and northern
Texas during summer, and as a result, a nocturnal precipitation maximum is not evident. Stability is large during summer due to the dominance of a midtropospheric anticyclone (Caracena and Fritsch 1983). The midlatitude westerlies are located considerably north of Texas, and the tropical easterlies rarely extend into central and northern Texas. Frontal passages and upper-level dynamics are essential for heavy rain formation in summer. Read (1985) found that nearly all of the summertime events in northern Texas not connected with tropical storms occurred in association with $200 \mathrm{mb}$ shortwave troughs and frontal boundaries. These features produce favorable conditions for convection during both day and night, and as a consequence, precipitation is more uniformly distributed throughout the day in summer.

Autumn is a transition period between the summer and winter precipitation regimes. In general, the nocturnal precipitation region of the central United States expands in areal extent, but the amount of expansion varies with precipitation intensity. The larger area experiencing an afternoon maximum for category 3 and 4 events compared to category 1-2 amounts suggests that the most intense precipitation occurs in early autumn when diurnal heating is still a major contributor to the formation of heavy precipitation. Earlier studies have reported a sharp decline in the number of extreme rain events from September to October for both the eastern two-thirds of the United States and the western United States (Maddox et al. 1979, 1980). The general expansion of the nocturnal precipitation from summer to autumn, especially for category 1-2 events, is likely a response to the increased frequency of migratory synoptic-scale systems with diurnally oscillating lowlevel winds during late autumn.

\section{Summary and conclusions}

This paper expands upon earlier studies of the diurnal characteristics of precipitation by documenting the diurnal variability of several categories of heavy hourly precipitation across the coterminous United States during winter, spring, summer, and autumn. In particular, the goal of this study was to identify the spatial variations in the diurnal cycle of heavy hourly precipitation as a function of both season and precipitation intensity. The major findings can be summarized as follows.

1) Seasonal variations in the diurnal cycle of heavy hourly precipitation are evident across much of the United States. These seasonal variations are greatest for the largest (category 2-4) precipitation rates. As expected, the diurnal cycle is weakest in the winter season and strongest during summer. An especially noteworthy seasonal variation is the expansion of the area experiencing a nocturnal precipitation maximum 
during winter, spring, and autumn to include much of the eastern and central United States, except the extreme Southeast and the Northeast. Correspondingly, the area experiencing a nocturnal maximum contracts during summer, as the daily boundary-layer heating cycle plays an increasingly significant role in initiating and intensifying convection, and a pronounced afternoon maximum becomes established over the eastern and southern United States.

2) The seasonality of the diurnal cycle varies with location. In some areas of the United States, such as the Northeast and the Great Basin, the diurnal phasing of heavy hourly precipitation varies little from season to season. Marked changes in the diurnal cycle with season occur elsewhere, particularly in central Texas, the central Gulf Coast, and the middle Atlantic seaboard.

3) Significant changes in the diurnal cycle of heavy hourly precipitation occur as precipitation intensity increases. During all seasons, the amplitude of the first harmonic at most locations increases as precipitation intensity increases. This increase implies that intense precipitation is confined to a shorter period of the day than light and moderate precipitation. Also, the phase of the diurnal cycle varies with increasing precipitation intensity. At most locations, lighter (category 1) precipitation events occur considerably earlier in the day than intense (category $2-4$ ) hourly precipitation rates. This is particularly true for spring and autumn, although a phase shift is evident even during summer when the diurnal cycle of precipitation is most strongly modulated. The major exception to this generalization is the nocturnal precipitation region where during all seasons the phase angle for heavier precipitation events precedes that of lighter events.

4) The markedly different diurnal characteristics of category 1 precipitation rates compared to category 24 rates lead us to conclude that category 1 events have diurnal characteristics similar to light and moderate precipitation and that it is inappropriate to refer to these events as "heavy" precipitation. We propose that a better definition of "heavy" hourly precipitation is an event in excess of $5 \mathrm{~mm} \mathrm{~h}^{-1}$.

5) and 6) Significance of the semidiurnal cycle is difficult to ascertain due to the dominance of the diurnal cycle over most of the United States. Secondary maxima and minima are most likely in the central United States from the Great Lakes to northern Kentucky and in eastern and central Texas, particularly for category 2-4 events.

7) The contradictory findings of previous studies on the time of day of greatest threat of heavy rainfall leading to flash floods appear partly to result from neglecting seasonal and regional variations in the diurnal cycle of heavy precipitation. Also, different definitions of "winter," "spring," "summer," and "autumn" can lead to divergent descriptions of the diurnal cycle, particularly during the cool season.
Acknowledgments. We are indebted to Dr. Jerome P. Charba, NOAA Techniques Development Laboratory, for his numerous helpful suggestions during the course of this work and for providing the software to calculate the precipitation frequencies. Thanks also go to Charles Rader, Michigan State University, and Les Howard, University of Nebraska-Lincoln, for preparing the illustrations. Constructive comments provided by Drs. Jay Harman, Randall Schaetzl, and Nancy Ettlinger and by the anonymous reviewers are gratefully acknowledged. Partial support for this work was provided by the NOAA, National Weather Service, Techniques Development Laboratory.

\section{REFERENCES}

Astling, E. G., J. Paegle, E. Miller and C. J. O'Brien, 1985; Boundary layer control of nocturnal convection associated with a synoptic scale system. Mon. Wea. Rev., 113, 540-552.

Balling, R. C., Jr., 1985: Warm season nocturnal precipitation in the Great Plains of the United States. J. Climate Appl. Meteor., 24, 1383-1387.

Belville, J. D., and N. O. Stewart, 1983: Extreme rainfall events in Louisiana: The "New Orleans Type." Preprints, Fifth Conf. on Hydrometeorology, Tulsa, Amer. Meteor. Soc., 284-290.

Blanchard, D. O., and R. E. López, 1985: Spatial patterns of convection in south Florida. Mon. Wea. Rev., 113, 1282-1299.

Bonner, W. D., 1968: Climatology of the low level jet. Mon. Wea. Rev., 96, 833-850.

Caracena, F., and J. M. Fritsch, 1983: Focusing mechanisms in the Texas hill country flash floods of 1978. Mon. Wea. Rev., 111, 2319-2332.

Carlson, T. N., 1980: Airflow through midlatitude cyclones and the comma cloud pattern. Mon. Wea. Rev., 108, 1498-1509.

$\longrightarrow$, S. G. Benjamin, G. S. Forbes and Y. F. Li, 1983: Elevated mixed layers in the regional severe storm environment: Conceptual model and case studies. Mon. Wea. Rev., 111, 14531473.

Changnon, S. A., Jr., and J. L. Vogel, 1980: The morphology of an isolated severe rainstorm and hydroclimatological characteristics of such storms. Preprints, Second Conf. on Flash Floods, Atlanta, Amer. Meteor. Soc., 5-10.

Charba, J. P., 1987: Zero-to-six and three-to-nine hour objective forecasts of heavy precipitation amount. NWS Tech. Procedures Bull. No. 370, National Oceanic and Atmospheric Administration, U.S. Dept. of Commerce, $14 \mathrm{pp}$. [Available from the Office of Meteorology, National Weather Service, 8060 13th Street, Silver Spring, MD 20910.]

Crysler, K. A., R. A. Maddox, L. R. Hoxit and B. M. Muller, 1982: Diurnal distribution of very heavy precipitation over the central and eastern United States. Natl. Wea. Dig., 7, 33-37.

Dexter, R. V., 1944: The diurnal variation of warm frontal precipitation and thunderstorms. Quart. J. Roy. Meteor. Soc., 70, 129137.

Fleming, E., L. E. Spayd, Jr. and R. A. Scofield, 1984: Characteristics of eastern region convective flash flood events in GOES imagery. Preprints, 10th Conf. on Weather Forecasting and Analysis, Clearwater Beach, Amer. Meteor. Soc., 409-417.

Giordano, L. A., and J. M. Fritsch, 1983: The a-typical mid-level flow for flash floods in the mid-Atlantic states. Preprints, Fifth Conf. on Hydrometeorology, Tulsa, Amer. Meteor. Soc., 142148.

Gray, W. M., and R. W. Jacobson, Jr., 1977: Diurnal variation of deep convection. Mon. Wea. Rev., 105, 1171-1188.

Grice, G. K., and R. A. Maddox, 1983: Synoptic characteristics of heavy rainfall events in south Texas. Preprints, Fifth Conf. on Hydrometeorology, Tulsa, Amer. Meteor. Soc., 149-155.

Guttman, N. B., and D. S. Ezell, 1980: Flash flood climatology for 
Appalachia. Preprints, Second Conf. on Flash Floods, Atlanta, Amer. Meteor. Soc., 70-72.

Holton, J. R., 1967: The diurnal boundary layer wind oscillation above sloping terrain. Tellus, 19, 199-205.

Hoxit, L. R., 1975: Diurnal variations in planetary boundary-layer winds over land. Bound. Layer Meteor., 8, 21-38.

Huff, F. A., 1978: Characteristic properties of midwestern flash flood storms. Preprints, Conf. on Flash Floods, Hydrometeorological Aspects, Los Angeles, Amer. Meteor. Soc., 29-33.

Kincer, J. B., 1916: Daytime and nighttime precipitation and their economic significance. Mon. Wea. Rev., 44, 628-633.

Landin, M. G., and L. F. Bosart, 1985: Diurnal variability of precipitation in the northeastern United States. Mon. Wea. Rev., 113, 989-1014.

McAnelly, R. L., and W. R. Cotton, 1986: Meso- $\alpha$-scale characteristics of an episode of meso- $\beta$-scale convective complexes. Mon. Wea. Rev., 114, 1740-1770.

Maddox, R. A., 1980: Mesoscale convective complexes. Bull. Amer. Meteor. Soc., 61, 1374-1387.

- C. F. Chappell and L. R. Hoxit, 1979: Synoptic and mesoalpha scale aspects of flash flood events. Bull. Amer. Meteor. Soc., 60, 115-123.

- , F. Canova and L. R. Hoxit, 1980: Meteorological characteristics of flash flood events over the western United States. Mon. Wea. Rev., 108, 1866-1877.

- K. W. Howard, D. L. Bartels and D. M. Rodgers, 1986: Mesoscale convective complexes in the middle latitudes. Mesoscale Meteorology and Forecasting, P. S. Ray, Ed., Amer. Meteor. Soc., 390-413.

Mass, C., 1982: The topographically forced diurnal circulations of western Washington state and their influence on precipitation. Mon. Wea. Rev., 110, 170-183.

Muller, B. M., and R. A. Maddox, 1979: A climatological comparison of heavy precipitation and flash flooding. Preprints, 11th Conf. on Severe Local Storms, Kansas City, Amer. Meteor. Soc., 249 256.

Passarelli, R. E., Jr., and R. R. Braham, Jr., 1981: The role of the winter land breeze in the formation of Great Lake snow storms. Bull. Amer. Meteor. Soc., 62, 482-491.

Pitchford, K. L., and J. London, 1962: The low-level jet as related to nocturnal thunderstorms over midwest United States. J. Appl. Meteor., 1, 43-47.

Read, W. L., 1985: Synoptic and subsynoptic aspects of summer season heavy rainfall in north Texas. Preprints, Sixth Conf. on Hydrometeorology, Indianapolis, Amer. Meteor. Soc., 28-33.

Reiter, E. R., and M. Tang, 1984: Plateau effects on diurnal circulation patterns. Mon. Wea. Rev., 112, 638-651.

Riley, G. T., M. G. Landin and L. F. Bosart, 1987: The diurnal variability of precipitation across the Central Rockies and adjacent Great Plains. Mon. Wea. Rev., 115, 1161-1172.

Schwartz, B. E., and L. F. Bosart, 1979: The diurnal variability of Florida rainfall. Mon. Wea. Rev., 107, 1535-1545.

Skaggs, R. H., 1969: Analysis and regionalization of the diurnal distribution of tornadoes in the United States. Mon. Wea. Rev., 97, 103-115.

- 1980: The diurnal distribution of large hail over the United States. Prof. Geogr., 32, 293-299.

Toth, J. J., and R. H. Johnson, 1985: Summer surface flow characteristics over northeast Colorado. Mon. Wea. Rev., 113, 14581469.

Vrcek, B. A., and W. E. Sangster, 1974: Climatology of heavy rains in the central United States. Preprints, Fifth Conf. on Weather Forecasting and Analysis, St. Louis, Amer. Meteor. Soc., 8789.

Wallace, J. M., 1975: Diurnal variations in precipitation and thunderstorm frequency over the conterminous United States. Mon. Wea. Rev., 103, 406-419.

Ward, J. D., 1981: Spatial and temporal heavy rainfall patterns over land associated with weakening tropical cyclones. Preprints, Fourth Conf. on Hydrometeorology, Reno, Amer. Meteor. Soc., 174-180.

Wetzel, P. J., W. R. Cotton and R. L. McAnelly, 1983: A long-lived mesoscale convective complex. Part II: Evolution and structure of the mature complex. Mon. Wea. Rev., 111, 1919-1937.

Winkler, J. A., 1987: Diurnal variations of summertime very heavy precipitation in the eastern and central United States. Phys. Geogr., 8, 210-224.

- 1988: Climatological characteristics of summertime extreme rainstorms in Minnesota. Annals, Assoc. Amer. Geographers, 78, 57-73. 